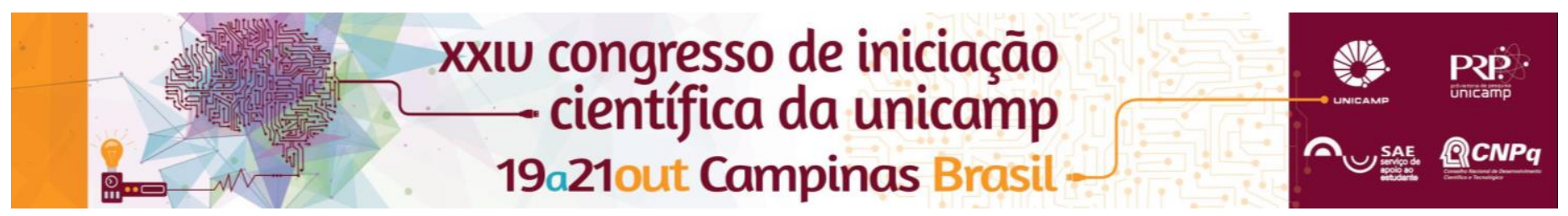

\title{
Cacófatos, ecos e colisões na polêmica sobre o Código Civil: a crise normativa brasileira
}

\section{Luísa H. Labello*}

\section{Resumo}

O objetivo do trabalho foi investigar o modo como os vícios de linguagem que afetam a fonologia, cacófato, eco, colisão e hiato, são tratados em textos da polêmica sobre o Código Civil brasileiro, levando em consideração a crise normativa que se instaurou no Brasil, na segunda metade do século XIX.

\section{Palavras-chave:}

Português do Brasil, Norma, História

\section{Introdução}

A polêmica sobre o Código Civil brasileiro teve início quando o senador Rui Barbosa publicou um parecer, analisando linguisticamente e arrumando todos os artigos que compunham o projeto do Código aprovado pela Câmara dos Deputados. Assim, a polêmica deixou de lado aspectos jurídicos e desencadeou uma longa discussão acerca do funcionamento da língua ${ }^{1}$. Um tópico que aparece de forma recorrente ao longo da polêmica são os vícios de linguagem. Assim, o principal objetivo deste trabalho foi analisar o modo como os vícios de linguagem que afetam a fonologia (cacófato, eco, hiato e colisão) são abordados no Parecer, na Réplica e em um conjunto de textos menores escritos à época por jornalistas, juristas e deputados, publicados pela Casa Rui Barbosa como Anexos à Réplica, levando em consideração a crise normativa brasileira que ocorreu no Brasil, no final do século XIX e início do século XX, devido a consolidação de uma nova norma culta.

\section{Resultados e Discussão}

Primeiramente, foi realizado um levantamento de gramáticas antigas da Língua Portuguesa, para examinar o momento aproximado em que os vícios de linguagem relacionados à pronúncia passaram a ser mencionados e como eles eram descritos. Foi encontrada uma citação ao cacófato já na Grammatica da língua portuguesa (1540), de João de Barros. Das vinte gramáticas analisadas, sete citaram algum desses vícios, definidos sempre como desagradáveis.

Em seguida, foi realizado o levantamento dos vícios de linguagem nos textos selecionados da polêmica.

No Parecer foi realizado um levantamento exaustivo dos casos que foram modificados por Rui Barbosa e um levantamento não exaustivo (até o art. 854) dos casos não corrigidos por ele. Foram utilizados os seguintes critérios para o levantamento dos dados: palavras marcadas em itálico nos artigos do projeto e corrigidas por Rui Barbosa, comentários acerca dos vícios, casos semelhantes aos que foram encontrados nas gramáticas analisadas.

Tabela 1. Casos modificados por Rui Barbosa

\begin{tabular}{|l|l|l|l|}
\hline Cacófato & Eco & Colisão & Hiato \\
\hline 60 & 199 & 635 & 122 \\
\hline
\end{tabular}

Tabela 2. Casos não modificados por Rui Barbosa

\begin{tabular}{|l|l|l|l|}
\hline Cacófato & Eco & Colisão & Hiato \\
\hline 7 & 59 & 168 & 212 \\
\hline
\end{tabular}

Com relação aos Anexos à Réplica, muitos dos textos acusavam o senador de cometer os mesmos vícios que foram apontados e corrigidos por ele no Parecer e de ter cometido muitos outros. Ao todo foram citados 48 cacófatos, 17 ecos e 9 colisões.

Por fim, na Réplica escrita por Rui, com o objetivo de analisar as críticas que sofreu de seus opositores, foram discutidos 18 tópicos sobre os cacófatos e 04 sobre os ecos terminados em ão, que são os mais modificados e discutidos por Rui.

Muitos foram os comentários encontrados no Parecer sobre os cacófatos que revoltaram os parlamentares, como a expressão "intrínseca validade" (Art. 14), considerada por Rui "(...) quase o necplus ultra do cacófaton." 2 Com relação aos ecos, Rui Barbosa parece se basear na prosódia ao afirmar que para evitar o eco, não se deve fazer o reparo nas palavras com o mesmo final, mas prestar atenção "(...) na sua distribuição em rima através da prosa." ${ }^{3}$ As colisões e os hiatos foram bastante arrumados no Parecer, mas pouco comentados e não causaram grandes revoltas por parte dos antagonistas de Rui.

\section{Conclusões}

O levantamento dos dados permite concluir que, apesar da grande quantidade de colisões e hiatos, os casos mais discutidos na polêmica foram os cacófatos e os ecos, que são definidos nas gramáticas analisadas como desagradáveis. Assim, as discussões sobre o primeiro código civil envolveram aspectos que foram muito além daquilo que a norma considerava certo e errado, levando em consideração os sons agradáveis e desagradáveis e aspectos da prosódia, por parte de Rui Barbosa.

\section{Agradecimentos}

Agradeço ao meu orientador, Prof. Dr. Emilio Gozze Pagotto, por todo o incentivo, a minha família por todo o suporte e ao SAE/UNICAMP pelo apoio financeiro.

${ }^{1}$ PAGOTTO, E. G. Rui Barbosa e a crise normativa brasileira. In: D. Callou e A. Barbosa (orgs.). A norma brasileira em construção: Cartas a Rui Barbosa (1866 a 1899). Fundação Casa Rui Barbosa, Rio de Janeiro, 2011.

2 BARBOSA, R. Parecer sôbre a Redação do Código Civil. In: Obras Completas de Rui Barbosa, 1902, v. XXIX, tomo I. Rio de Janeiro, Ministério da Educação e Saúde, 1949.

${ }^{3}$ BARBOSA, R. Réplica. In: Obras Completas de Rui Barbosa, 1902, v. XXIX, tomo II. Rio de Janeiro, Ministérios da Educação e Saúde, 1953. 